\title{
Correction to: Happy Helpers: A Multidimensional and Mixed-Method Approach to Prosocial Behavior and Its Effects on Friendship Quality, Mental Health, and Well-Being During Adolescence
}

\section{Daye Son ${ }^{1}$ (D) - Laura M. Padilla-Walker ${ }^{2}$}

Published online: 5 November 2019

(c) Springer Nature B.V. 2019

\section{Correction to: Journal of Happiness Studies https://doi.org/10.1007/s10902-019-00154-2}

In the original publication, under Abstract section and in the Participants (2.1) section under Methods, the phrase "[project name masked for review]" should read as "Flourishing Families project"

Publisher's Note Springer Nature remains neutral with regard to jurisdictional claims in published maps and institutional affiliations.

The original article can be found online at https://doi.org/10.1007/s10902-019-00154-2.

Daye Son

dson9@asu.edu

1 T. Denny Sanford School of Social and Family Dynamics, Arizona State University, 951 S. Cady Mall, SS 144, Tempe, AZ 85287, USA

2 School of Family Life, Brigham Young University, 2071 JFSB, Provo, UT 84602, USA 